\title{
Signs and the design of life - Uexküll's significance today: A symposium, its significant history and future
}

\author{
Torsten Rüting ${ }^{1}$
}

One may find many reasons to commemorate and celebrate Jakob von Uexküll in 2004: the 140th anniversary of his birth, the 60th anniversary of his death or 70 years since the publication of his famous book $A$ Stroll through the Umwelten of Animals and Men (Uexküll, Kriszat 1934). Hamburg University may celebrate that it had called Uexküll to Hamburg 80 years ago. However the plan to organise an international symposium taking place on January 9th to 11th 2004 at the University of Hamburg was not driven by the wish to venerate biographical history. Though taking place at the Centre for the History of Science, Mathematics and Technology, the symposium celebrated primarily a very recent occasion and its agenda demonstrated the contemporary interest in Jakob von Uexküll among international academia: The inauguration of a Jakob von Uexküll Archive for Umweltforschung and Biosemiotics at the University of Hamburg, housing and maintaining a part of the scientific Nachlass of Uexküll and the library of the former Institut für Umweltforschung was the foremost reason to celebrate. It had taken many years and problems until this plan was finally realised. It had been projected in 1983 by Thure von Uexküll (1908-2004), who had therefore gifted the scientific library of his father to Hamburg. So the successful realisation of the maintenance of an essential element of the famous tradition of the still young University of Hamburg is already an episode of the university's history itself. The story of the Nachlass seems to reveal and repeat the difficulties that Uexküll had to face, when he tried to institutionalise his biology at the university. Uexkülls's approach, that would be called "interdisciplinary" today, was untimely and did not fit into the scheme of institutions. After 35 years of struggling in a no-man's-land between faculties the Institute für Umweltforschung was closed in 1960. The wealth of Uexküll's work and the

Author's address: Torsten Rüting, Jakob von Uexküll-Archiv für Umweltforschung und Biosemiotik, Fachbereich 11, Universität Hamburg, Bundesstr. 55, 20146 Hamburg, Germany; e-mail: rueting@math.uni-hamburg.de. 
tradition that had formed in Hamburg remained unacknowledged by most of the established biologists there. The Nachlass of the Institut für Umweltforschung was seen more or less as a collection of curiosities and the plan for an archive was long neglected. It was through the commitment of colleagues and students of Tartu University that Hamburg University came to acknowledge the significance of its own famous biologist. The founding and the engaged activities of the Jakob von Uexküll Centre in Tartu (described by Magnus et al. 2004) convinced Thure von Uexküll to suggest to send the collected materials to Tartu, where the tradition of his father and his biosemiotic approach had found obvious followers and fruitful continuation. The following request to send the Nachlass to Tartu provoked a heated debate among officials at Hamburg University. As an effect, scholars like Eckart Krause, head of the Hamburger Bibliothek für Universitätsgeschichte, who were aware of the significance of Uexküll and the Institute für Umweltforschung for their university spoke out against the transfer of the Nachlass. It was emphasised that the materials were part of the university's possessions, represented its tradition and were to be kept and presented to its academia.

During the 2nd Gatherings in Biosemiotics taking place in 2002 in Tartu, a founder of the Jakob von Uexküll Centre, Kalevi Kull, from Tartu University and Torsten Rüting from the Centre for the History of Science, Mathematics and Technology of Hamburg University met and agreed to cooperate in the further maintenance of the Nachlass in order to make it available to the international community, interested in the history of Uexküll and the development of alternative approaches in the interdisciplinary fields between biology and the humanities that he had encompassed. These plans were presented to officials of Hamburg University. The director of the Zoological Institute and Museum, Olav Giere, proposed to give the materials to the Centre for the History of Science Mathematics and Technology. The head of the Centre, Karin Reich and the head of the department of mathematics, Alexander Kreuzer, agreed to house and to maintain the archive in their building. It was decided to celebrate the opening of the archive and to hold an international symposium, which was generously funded by the department and different foundations. All of the invited scholars agreed to give a talk in Hamburg and others, like Myrdene Anderson from Purdue University and Wolfgang Alt from Bonn came just to attend the symposium. Unfortunately Thure von Uexküll, who was pleased to see his plans realised became ill and the paper that he had prepared had to be read to the audience. But another prominent member of the Uexküll-family, Jakob von Uexküll's grandson, Jakob von Uexküll Jr., founder of the Right Livelihood Award, the so called "Alternative Nobel Prize", came in from London to explain what the visionary ideas of his grandfather might mean for the struggle for right livelihood in a world threatened by the destruction of the environment and the diversity of Umwelten in a globalised world. 
As already indicated by its name the archive's agenda is to integrate the tradition of Uexküllian Umweltforschung and the conception of biosemiotics. In this sense the work of the archive should primarily contribute to studies about epistemology and ethics in the life-sciences that are integrating studies of nature and studies of culture. This means on the one hand to continue the lifework of Uexküll, whose prime motive at the outset of his profession was to ground biology on a sound epistemological and ethical basis and make it a modern experimental science (Rüting 2004). On the other hand it means to catch up with the recent progress in an interdisciplinary movement that gathers under the label of biosemiotics and represents a broad initiative of developments that are integrating biological, cognitive and cultural scientific approaches.

To many of the German audience of Jakob von Uexküll and those who see him primarily in the context of ethological and ecological research it might be necessary to explain how Uexküll came to be recognized as a pioneer of biosemiotics. In 1977, after Thomas A. Sebeok (1920-2001) had described Uexküll as a "Neglected figure in the history of semiotic Inquiry" on a conference in Vienna (Sebeok 1989), Sebeok and Jakob von Uexküll's son Thure, professor at Ulm and founder of psycho-somatic medicine in Germany, met and the work of the elder Uexküll was introduced to a wider circle of scholars interested in the semiotic analyses of life. The further story has already been published by Sebeok (1998) and Kull (1989, 1999, 2001) and will also be addressed by Deely in this volume. The new approach of Biosemiotics flourished especially in Tartu and finally led to the foundation of the Jakob von Uexküll Centre there in 1993. Inspired by the tradition of the Tartu semiotic school of Juri Lotman, the concerned intellectual scope of Thomas A. Sebeok (Deely 2004) and backed by a new discovery of the semiotic contents of the philosophy of Charles S. Peirce mainly by Danish scholars, the rediscovery of Jakob von Uexküll was pushed forward for modern academia.

These exciting developments have at least now reached Hamburg. The Symposium was a starting point for a rediscovery of one of its members as a pioneer thinker for the international development of science. This volume also shows that the university of Hamburg has a rich tradition which can be seen as a part of the vanguard in modern thought that might constitute new foundations for science and research in the 21 st century. The exceptional cooperation and communication of scientists like Ernst Cassirer, William Stern, Heinz Werner and Jakob von Uexküll in the 1920ies and early 1930ies led to innovative ideas (Steckner and Krois, this volume) and after inspiring postmodern philosophy (Chien, Weber, this volume) the seeds of these untimely developments might now help to overcome the stasis of postmodernity.

Already a look at the program of the symposium and the table of contents of this special issue documenting it, show that Uexküll has again become a focal point for international academia and links scholars in different parts of the 
world covering very different fields of research. Han-liang Chang from National Taiwan University traced the traditions of phenomenology and hermeneutics as a field of context and influence around Uexküll. The second scholar from National Taiwan University, Juipi Chien, discussed Uexküll's concept of form by examining the different contexts in which he reasons with expressions like Schema, Form, Gestalt and comes to situate Uexkülls theory near the paradigm of structural linguistics. Tobias Cheung who had come from the University of Paris and now teaches at Humboldt University in Berlin emphasised how deeply Uexküll's theorising was founded in contemporary research and debate about biological self-organisation in developing cells and organisms.

John Deely, professor from the University of St Thomas in Houston, who witnessed how Thomas A. Sebeok introduced Thure von Uexküll to the Semiotic Society of America in the early 1980ies and since then accompanied the development of biosemiotics from the critical stance of Thomist philosophy, gave an account of his understanding of the significance of Uexküll's concept of Umwelt in this process. Matthias Gutmann, professor for philosophy in Marburg, started with a critical revaluation of Uexküll's theory of organism and gave an elaborated constructivist reinterpretation and reformulation of it, which may be used to systematise and to structure future biological research. Another critical evaluation was presented by Jesper Hoffmeyer, professor at the Institute of Molecular Biology of the University of Copenhagen. In order to save the initiative of biosemiotics from unfruitful discussions, he conversed the problem of Uexküll's notion of design or Planmäßigkeit and their inherent impression of teleology and determinacy. The paper by John Michael Krois, professor at the Institute of Philosophy at Humboldt University of Berlin, who is currently editing the correspondence and unpublished works of Ernst Cassirer, documented how deeply Cassirer's later works were influenced by Uexküll, his collegue at Hamburg University. Also tracing the influence of Uexküll on Cassirer, Andreas Weber then tried to formulate a comprehensive semiotic anthropology for the integrative understanding of human nature and culture. Seeing Uexküll as an early pioneer overcoming of neodarwinian theories, Anton Markoš, professor at Charles University in Prague, explained the ideas of the biophysicist Stuart Kauffman and semiotic linguist Juri Lotman, who according to him best described the continuous negotiation (semiosis) of 'laws' that govern the evolution of organisms, minds and cultures, driving them to ever larger autonomy. The paper by Magnus, Maran \& Kull described the decade long activities on the fields of biosemiotics, ecosemiotics and the philosophy of nature that were organised and promoted by the Jakob von Uexküll Centre in Tartu. The art historian Cornelius Steckner from Cologne described the context of artistic and philosophical studies around the concept of Uexküll and Cassirer in the 1920ies and 30ies. Torsten Rüting brought to memory the 
historical and biographical developments that led to the historical and present significance of Jakob von Uexküll. ${ }^{2}$

\section{References}

Deely, John 2004. Semiotics and Jakob von Uexküll's concept of umwelt. Sign Systems Studies 32(1/2): 11-34.

Kull, Kalevi 1998. Semiotic ecology: different natures in the semiosphere. Sign Systems Studies 26: 344-371.

- 1999. Biosemiotics in the twentieth century: a view from biology. Semiotica 127(1/4): 385-414.

— 2001. Jakob von Uexküll: An introduction. Semiotica 134(1/4): 1-59.

Magnus, Riin; Maran, Timo; Kull, Kalevi 2004. Jakob von Uexküll Centre, since 1993. Sign Systems Studies 32(1/2): 375-372.

Rüting, Torsten 2004. History and significance of Jakob von Uexküll and his institute in Hamburg. Sign Systems Studies 32(1/2): 35-72.

Sebeok, Thomas A. 1989. The Sign and its Masters. Houston: University of Texas Press.

- 1998. The Estonian connection. Sign Systems Studies 26: 20-41.

Uexküll, Jakob von; Kriszat, Georg 1934. Streifzüge durch die Umwelten von Tieren und Menschen (Ein Bilderbuch unsichtbarer Welten). (Verständliche Wissenschaft, Bd. 21). Berlin: J.Springer.

2 Acknowledgements go to Carl-Christiansen Gedächtnis-Stiftung, Hamburg; The Department of Mathematics, University of Hamburg; Wilhelm BlaschkeGedächtnis-Stiftung, Hamburg; Hans Schimank-Gedächtnis-Stiftung, Hamburg. 